\title{
Technology: The classic Canadian dilemma-Short-term gain for long-term pain!
}

\author{
by Joseph D. Wright
}

In a globally competitive world, innovation is an essential component of long-term success. For commodity industries in particular, global companies will dominate, with niche-market, nimble, small companies providing specialized products to select customers. Both will require technology. To survive in international markets, Canadian pulp and paper producers must develop integrated business and technology strategies to meet global competition from low-cost fibres and state-of-the-art mills. For competitive positioning, and for increased returns on investment, the mandatory progress in cost reduction must be balanced with revenue growth through new product innovations. Companies can leverage their limited resources through participation in the programs of a research institute. Paprican, as an example, provides access to broadly based technical skills in areas related to cost reduction, and environmental sustainability. At the same time, it delivers world-class, strategically driven research that enables new product design and development. For technologies related to public policy directives such as environmental performance or global warming initiatives, governments must participate as stakeholders in the solutions to their issues.

Key words: pulp and paper industry, international competitiveness, research and development, research institutes, innovation, return on investment, multidisciplinary research, public policy

En vertu d'une compétition qui s'étend à l'ensemble de la planète, l'innovation est un élément essentiel du succès à long terme. Pour les industries du secteur des commodités, en particulier, les entreprises multinationales domineront, accompagnées de petites compagnies opportunistes couvrant des niches spécifiques de produits spécialisés pour des clients précis. Tous deux auront besoin de technologie. Afin de survivre sur les marchés internationaux, les producteurs canadiens de pâtes et papiers devront développer des entreprises intégrées et des stratégies technologiques pour faire à la compétition mondiale provenant des fibres à faible coût et des usines à la fine pointe technologique. Afin d'occuper un créneau compétitif, et pour accroître le retour sur l'investissement, le progrès obligatoire en matière de réduction de coûts doit être contrebalancé par la croissance des revenus provenant des innovations reliées aux nouveaux produits. Les compagnies peuvent faire une meilleure utilisation de leurs ressources limitées par la participation à des programmes des instituts de recherche. Paprican, par exemple, procure un accès aux habiletés techniques générales reliées à la réduction des coûts, et à la durabilité de l'environnement. Parallèlement, il procure des résultats de recherche de classe mondiale stratégiquement orientés qui permettent la conception et le développement de nouveaux produits. Pour ce qui est des technologies reliées directives de politiques publiques comme la performance environnementale ou les initiatives sur les changements climatiques, les gouvernements doivent participer en tant qu'intervenants au niveau des solutions des ces enjeux.

Mots-clés : industrie des pâtes et papiers, compétitivité internationale, recherche et développement, instituts de recherche, retour sur l'investissement, recherche multidisciplinaire, politique publique

\section{Introduction}

When times are tough, cutting research is just not good enough! In fact, reducing investments in technology is inconsistent with well-established evidence to the contrary. Case histories show convincingly that companies that maintain their longterm strategic investments deliver superior returns compared with their competitors. Innovation is an essential component of long-term sustainability. So, why is there so much evidence of cutbacks in the research and technology agenda?

The Canadian forestry sector, and Canada's largest contributor to net revenue, is currently experiencing some of the most difficult market conditions in more than 30 years. On a global basis, the pulp and paper industry is under stress. Profits are down. Returns on capital investment have been dismal for years. Companies are taking downtime in many of their mills. Worldwide, consolidation forces are driving the industry. Shareholders are unhappy. Many company executives have their feet to the fire, and are intently focused on the quarter ahead. Public perceptions of the industry range from negative to neutral. North American capital installations are below state-of-the-art in scale and technology. Cost reductions are king.

${ }^{1}$ President and CEO, Paprican, 570 St. Jean Boulevard, Pointe-Claire, Quebec H9R 3J9. E-mail: Jwright@ paprican.ca
Fibres, which for years produced a real Canadian advantage, have been attacked through advances in processing and performance of southern pines for softwoods, and plantation eucalyptus for hardwoods. In a recent conversation, a Canadian company representative observed that his plant capacity was at $50 \%$ compared with the best Nordic companies, and his fibre, energy, and human

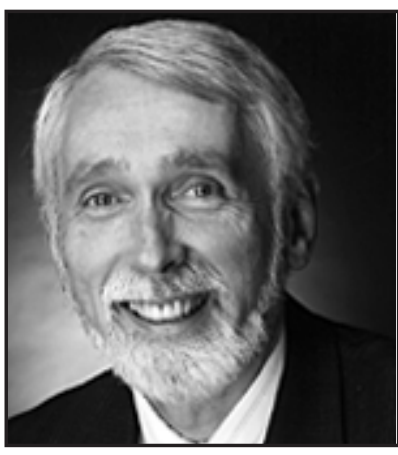

Joseph D. Wright resource costs were certainly not significantly lower, so how could he hope to survive in world markets that were oversupplied with raw materials?

The Canadian problem statement might read something like: How do we generate superior returns on investment in highly competitive, oversupplied commodity markets, with increased incursion on world markets from foreign fibres. In addition we have plant and equipment well behind current stateof-the-art technology, and compete through companies that, in general, are small on a world scale. How can we provide returns to our investors given the toughness of our business? 


\section{R\&D in Decline}

Of 12 Canadian pulp and paper companies that had some level of in-house company research in November 1997, six companies no longer exist by virtue of having been acquired. Of the remaining six, two have shut down their research centres, leaving only four with in-house research organizations as a visible component of corporate capability. Five of those six companies invest considerable resources in Paprican as part of their corporate strategy for technology. Outsourcing technology support to Paprican, while admirable in its strong statement that technology does matter, is not an adequate response to foreign competition. Our powerful global competitors invest heavily in technology, in both capital and in-house technical capability, in addition to championing their own research institutes.

Like it or not, we live in a globally competitive world. Further, the products of this industry fall in the class of commodities, even though they may well be rather sophisticated in nature. In commodity businesses, the focus is frequently on cost, and the Canadian industry is certainly not losing track of this line of thought. Over decades, commodity prices decline relentlessly. Martin and Porter (2001), in their report on Canadian competitiveness, highlight this point with a graph showing longterm trends in commodity prices over 200 years. The Chatham House Forum Web site ${ }^{2}$ describing scenarios for 2020 illustrates industry profit in commodity businesses in which the price is set by the marginal firms, and with the overall profit envelope shrinking relentlessly as technology lowers the overall costs of production.

To compete, it is necessary to be a low-cost producer, but the risk in all commodity businesses is that shrinking margins erode profitability for all competitors. A quote from the executive summary of the 1996 Chatham House Forum Report entitled "Unsettled Times" captures the challenge. "If commoditization continues to prevail, then firms will be caught in an endless race to stay in the same place, with an obviously adverse social impact. If innovation proves to be the stronger driving force and the sources of advantage can remain defensible, then profitability will also be strong" (The Royal Institute of International Affairs 1996).

Returns on investment, from a shareholder point of view, can be seen as positive cash flows, or growth in share value as a ratio of overall growth in revenue compared with overall reductions in costs. The direction that has received the predominant focus from most of the Canadian pulp and paper producers has been to concentrate on cost reduction as a way to increase returns. This is necessary to remain in the competitive game. However, it really should be viewed as the ante in a high stakes game- not as the bet that will win the table. A company must position itself competitively to grow revenue, and this must be implemented through risk-taking in new product areas.

Parallels with the steel industry are interesting. Most of the North American industry is operating under very challenging competitive conditions and many companies are on the verge of bankruptcy. Over the past decade, many or most of these companies have reduced their internal expenditures on research and technology. They have preferred to rely on outside technology from suppliers, or to make minimal investments to reduce overall operating costs. When a company relies very heavily on its suppliers for technology, where is the competitive advantage? Most suppliers, even those who are willing to enter proprietary development agreements with very large companies, are in business to sell their products to the largest possible markets. So even technologies that are developed through proprietary arrangements will ultimately find their way into the broad product offerings of a supplier company. Capital investments have been curtailed so that over time, the capital assets have declined in value.

A notable exception is Dofasco, which, over the same decade, has substantially increased its investments in research and technology. The result is, that of all the North American steel companies, Dofasco is one of the most profitableclearly a signal that technology can make a difference.

Recognition of the declining resources for science and technology has taken an interesting twist in the United States. Cost pressures there, too, have provoked downsizing or closure of many of the traditional industry R\&D centres. Simultaneously, many suppliers to these industries have also reduced these expenditures. In face of these actions there is, nonetheless, recognition that advances in many areas, such as biotechnology, genomics, communications, semiconductors, mechatronics, to name only a few, are moving at a more rapid pace than ever before.

\section{Technology Strategy}

A technology vision for the Forest industry was published in 1994 at the encouragement of the U.S. Department of Energy. It is called Agenda $2020^{3}$. More recently, a Technology Summit was organized by the American Forest and Paper Association, the Technical Association of the Pulp and Paper Industry, and the U.S. Department of Energy's Office of Industrial Technology, to update this strategy. Details are being published by TAPPI \& PIMA in Solutions (Raymond 2001). The attempt is to define a bold new strategy for breakthrough technologies, developed on a pre-competitive basis, which can rapidly move the industry to a higher state of profitability. The theory is that such breakthrough technologies can and should be developed through collaboration of industry, academia and government. The challenge was, and is, where will this work be done, and how will it be funded? Clearly, there is an expectation that government will play a major role. Industry CEOs have expressed strong support but the investment to implement the evolving strategy still appears to be at risk.

Through all this, what has been happening in the Canadian Industry, and for the sake of this article, the pulp and paper sector? First of all, the consolidation of the industry is well under way. There are far fewer companies operating in Canada than there were even two or three years ago. Despite this, the new companies remain small compared with the size of our most competitive, global leading companies. Much of Canadian industry depends heavily on Paprican for research and technology.

In 1999, under pressure from the global forces in this industry, and in response to a strong Member Company

${ }^{2}$ Chatham House Website, www.chforum.org/scenario/c10.html, November 2001.

\footnotetext{
${ }^{3}$ Agenda 2020 http://www.agenda2020.org/home.htm
} 
requirement to reduce the costs of this pre-competitive research, Paprican developed a strategy for globalization. The strategic positioning assumes that for a corporate business strategy to be successful, it must have global markets in focus. Furthermore, for long-term success, a business strategy must encompass technology. Focusing on current Member Companies of Paprican, comprised only of Canadian mills, the underlying idea was that their business strategies would include technology for their worldwide operations. Classes of membership were expanded to allow for these Member Company mills outside Canada to have access to Paprican technology, and to participate in the goal setting of the research programs. Paprican's position is to be a strategic technology partner with its Member Companies. The ideas of adding value, whether to grades and classes of market pulp, newsprint, and fine papers, or to invent products with new functionality that could even find synergies with the newer forms of electronic communications were included in revisions to Paprican's Technology Strategy.

As part of its Business Plan, Paprican has repositioned its research and technology staff to have a clear understanding of the business value of the work they do. Recent articles on managing innovation provide important insights for effective solutions to the complex problems of modern technology (see, for example, Heggy 2001). The key is that multidisciplinary thinking, promoting a systems-oriented approach to technology development will set the context for science and engineering in the 21 st century. "New dimensions of complexity, scale, and uncertainty in technical problems put them beyond the reach of one-thought disciplines." Further, the "benefits of multidisciplinary thinking - and shortcomings of a world that is deconstructed and understood primarily by specializationhave been apparent for several decades." It also stated that "more research is being done in centres, in conglomerate settings where all disciplines are needed and in which extra-disciplinary knowledge is at a premium."

\section{Paprican is Multidisciplinary}

Paprican has positioned itself to maintain a broadly based, multidisciplinary team approach to the many technologies that are relevant to Member Companies. The role and strength of institutes like Paprican, which maintain a broad spectrum of technical capabilities, is that we are able to integrate across the disciplines. We are a symphony orchestra, able to play the most complex music, and at the same time, we are able to use the individual components to provide the specialized services that are analogous to a string quartet, a trumpet solo, or a chamber orchestra. Industry decisions to outsource technology and to focus on narrow access to specialists depend upon an in-house ability to do the technology integration. Those global companies that retain this ability will often miss the pure science focus in individual areas. Hence, they will require profound science and technology expertise, whereas many others will need the integration capability.

Not to lose track of the return on investment (ROI) ratio, Paprican's Technology Strategic Plan encompasses three thematic areas. First, it targets the growth component of the ROI equation, with a focus on product performance. The intent is to enhance quality and functionality of potential Member Company products through strategic development of technology platforms. Improvements to existing products will continue, while lay- ing groundwork for development of whole families of future products. For companies to make best use of outsourcing technology acquisition, it is cost-effective to work from strategic technology platforms and ideas, and thus leverage their investment costs. Secondly, a focus on cost reductions maintains a direct connection to the inevitable decline in commodity cost curves. Here the thrust is to seek continuously to reduce the costs of raw materials, energy, chemicals and processing, maintaining a position on the relentless commodity price curves. Finally, major areas related to public policy directives must be maintained for improved environmental performance including sustainable development technologies. The key is to relentlessly pursue reductions in air, water, and particulate emissions while seeking to enhance product performance and to maintain or lower the costs of operation.

In delivery of technology, companies are looking for value on both the numerator and the denominator of their ROI results. This fits well with the requirements of performance for a world-class research and technology organization. To compete at the pure research level, Paprican must be able to attract world-class scientists and engineers. They provide a link to the fundamental science of technologies relevant to our industry, bringing comprehension and valuable solutions to the operational problems observed both in manufacturing and in product performance. At the same time, it is critical that technologies are delivered to and implemented in Member Company mills. The technology delivery capability comes from highly trained and motivated researchers who have spent considerable time in production or product environments. The synergies between these two complementary skill sets are what provide the maximum value to our customers.

\section{A Strategy for Canada}

In this competitive world, with enormous pressure to deliver value to customers at the lowest possible cost and with maximum quality, every industry is seeking to maximize its efficiency and effectiveness. Global companies will dominate markets, with niche-market, nimble small companies providing specialized products to select customers. For industries that are essential to national fiscal performance, all stakeholders must engage. The Canadian Forestry Sector must recognize, and respond to the forces of global competition. Technology will be a component of the business plans of those companies that survive. In-house capability to implement new technologies, enable new product ideas, and reduce cost, will be crucial. For areas where public policy initiatives and concerns affect operations of manufacturing companies, government must be a participating stakeholder in the solutions to their issues. Our global competitors enjoy this support already.

For organizations that provide technology as a primary product, world-class performance will be mandatory, and the breadth of their multidisciplinary services must be maintained. Research Institutes will need to address the needs of global companies. At the same time they must provide exemplary services to those companies that will focus on niche market opportunities, and which by virtue of their size, may rely heavily on external support for their technology initiatives. Academic research will deliver new opportunities for synergies between current and emerging technologies, as technical innovations provide new ways to deliver product service and value to discerning customers. 
Despite many opinions to the contrary, paper manufacturing will continue to exist for many years to come. To support its continued and necessary productivity, industry and government must work together. Together they must ensure that investments in science and technology are made in support of fiscal as well as societal success.

\section{References}

Heggy, P.H. 2001. Inside R\&D. Managing Innovation 30(41): 5-6.
Martin, R.L. and M.E. Porter. 2001. Canadian Competitiveness: A Decade after the Crossroads. http://www.mgmt.utoronto. ca/research/competitive1.htm

Raymond, D.R. 2001. Setting the industry's technology agenda. Solutions 1(1): 64-67.

The Royal Institute of International Affairs. 1996. Unsettled Times: Three Stony Paths to 2015, the 1996 Chatham House Forum Report. 